Reprod. Nutr. Dévelop., 1986, 26 (2 B), 607-615.

\title{
Mammary metabolism in the goat during normal or hormonally-induced lactation
}

\author{
Y. CHILLIARD (1), C. DELOUIS (2), Mary C. SMITH (3), D. SAUVANT $\left({ }^{4}\right)$, \\ P. MORAND-FEHR $\left({ }^{4}\right)$
}

with the technical assistance of H. GRABOWSKI (2), Françoise HOULIER (5). Annie ROUZEAU (4) and J. HERVIEU (4)

(1) Laboratoire de la Lactation, I.N.R.A., Theix 63122 Ceyrat France.

(2) Laboratoire de Physiologie de la Lactation, I.N.R.A., 78350 Jouy-en-Josas.

(3) N.Y.S. College Veterinary Medecine, Cornell University Ithaca, N.Y. 14853, USA.

(4) Station de Nutrition et d'Alimentation, INAP-G, 75005 Paris.

(5) Station de Nutrition, I.N.R.A., 78350 Jouy-en-Josas.

Summary. Mammary metabolism was studied in 4 normal lactating goats (group $N$ ) and in 4 non-pregnant goats induced to lactate by hormonal treatment (group 1). Tissue was sampled by biopsy after 3,9 and 18 weeks of lactation. Although milk potential was the same in both groups, group I produced $45 \%$ less milk than group $\mathrm{N}$.

The RNA/DNA ratio, activities of lipoprotein lipase (LPL), glucose-6-phosphate dehydrogenase and acetyl-CoA carboxylase, and the $\beta$-casein $\%$ of in vitro protein synthesis were not significantly lower in the $\mathrm{I}$ than in the $\mathrm{N}$ goat mammary tissue. This suggests that differences in mammary cell hyperplasia during hormonal treatment, and not potential metabolic activities, partially accounted for the difference in milk yield levels.

Milk composition was comparable in the two groups. However, milk fat in group $\mathrm{N}$ had a higher long-chain fatty acid content (stearic and oleic acids) during the first month of lactation due to the higher mobilization of body lipids in high-yielding animals. Another qualitative difference was the delayed increase in milk LPL secretion during the first 3 months of lactation in induced goats.

\section{Introduction.}

Few studies have been done on changes in the metabolic activities of mammary tissue during lactation in cows (Currie, 1972; Shirley, 1973 ; Marinez et al., 1976) and goats (Marinez et al., 1976 ; Chilliard et al., 1978 ; Reddy and Ray, 1982 ; Knight and Peaker, 1984). Only one experiment of this type was conducted on non-pregnant cows induced to lactate by hormonal treatment (Collier et al., 1976).

The aim of the present work was to compare changes in the different metabolic activities of the mammary tissue in goats during normal or hormonally induced lactation and to assess if they were closely related to milk yield and the secretion of milk fatty acids and proteins. 


\section{Material and methods.}

Two groups of 4 multiparous goats of the French Alpine breed 3 to 5 years old and having the same milk potential (table 1) were compared. Group $\mathrm{N}$ (normal goats) ( ${ }^{1}$ ) included goats that were already pregnant and group I (induced lactation) non-pregnant goats receiving an hormonal treatment programmed so that both groups began lactation at the same time. This treatment was applied in December.

The hormonal treatment given to group I goats (Delouis, 1975) began 22 days before the goats were milked. Injections of progesterone $(31 \mathrm{mg})$ and of $17 \beta$ oestradiol $(12.5 \mathrm{mg})$ were given twice daily for 7 days, followed by $25 \mathrm{mg}$ of hydrocortisone between days 18 to 22 after the onset of the treatment. The hormones were from Roussel-Uclaf.

When they were dry, i.e. 10 weeks before lactation, all goats received a diet containing $75 \%$ lucern hay and $25 \%$ concentrates. This diet covered about $130 \%$ of the energy maintenance requirements $175 \mathrm{~g}$ of ration per $\mathrm{kg}$ of metabolic weight, $\mathrm{P}^{0,75}$ ). During lactation all the animals were given lucern hay $a d$ libitum and $500 \mathrm{~g}$ of concentrate (for a $60-\mathrm{kg}$ goat), as well as $250 \mathrm{~g}$ concentrate per $\mathrm{kg}$ of milk yielded beyond $1 \mathrm{~kg} /$ day.

The milk yield of the goats was measured every day and its fat and protein contents each week on representative samples from 2 consecutive milkings. Fatty acid composition (Bas, 1985) and lipoprotein lipase activity (Chilliard and Fehr, 1976) of the milk were measured at 1, 3, 6, 9, 12, 15 and 18 weeks of lactation.

Mammary tissue was sampled by biopsy at weeks 3,9 and 18 : the goats were given a tranquillizer (Rompun, Bayer, $0.1 \mathrm{mg} / \mathrm{kg}$ live weight), then $5 \mathrm{ml}$ of procaine were infiltered under the skin in the upper-posterior part of the mammary gland. After the skin was incised with a scalpel, about $5 \mathrm{~g}$ of secretory tissue were cut off with scissors.

The mammary tissue was rinsed in saline, dried on a blotter and dissected. Aliquot parts were either deep-frozen for different assays, or kept cold for $1 \mathrm{~h}$ before incubation ( $3 \mathrm{~h}$ with ${ }^{14} \mathrm{C}$-labelled amino acids) to measure the amount of $\beta$ casein (after immunoprecipitation) in the proteins synthesized in vitro ( $\% \beta$-CAS), as described by Skarda et al. (1982).

The activities of acetyl-CoA carboxylase (ACX), glucose-6-phosphate dehydrogenase (G6PDH) and lipoprotein lipase (LPL) were measured in mammary tissue as described by Pascal et al. (1977), Fitch et al. (1959) and Chilliard (1979, 1985). The first two enzymes are involved in the de novo synthesis of fatty acids, the third in the hydrolysis and the uptake of circulating triglycerides.

Nucleic acid levels were measured as described by Schmidt and Tannhauser (1945). RNA and DNA levels were estimated in the supernatants of the alkaline

(1) List of abbreviations : Group 1: goats with hormonally-induced lactation : group $N$ : normal goats; ACX : acetyl-CoA carboxylase; RNA (DNA) : (deoxy) ribonucleic acid; G6PDH : glucose 6-phosphate dehydrogenase; LPL : lipoprotein lipase ; $\beta$-CAS : proportion of $\beta$-casein in in vitrosynthesized proteins. 
and acid hydrolyses, respectively, using absorption differences at 260 and $310 \mathrm{~nm}$.

The results were analysed using non-parametric tests (Tomassone, 1981), the $\mathrm{U}$-test of Mann-Whitney to compare the groups, and the sign test (binomial law) to compare the lactation stages (intra-animal variation).

\section{Results and discussion.}

Milk yie/d. - The maximal weekly milk yield of former lactations, by which animal milk potential was estimated, was identical in the 2 groups (table 1). During experimental lactation, group $\mathrm{N}$ reached its milk potential, while group I yielded only about $55 \%$ of that potential $(P<0.015)$.

\section{TABLE 1}

Maximal weekly milk yield in the two experimental groups (kg/week).

\begin{tabular}{cccccc}
\hline Goats & \multicolumn{3}{c}{ Previous lactations $(\mathrm{a})$} & \multicolumn{3}{c}{ Experimental lactation } \\
\hline Normal & 29.3 & $( \pm 2.7)(\mathrm{b})$ & & 29.5 & $( \pm 2.0)$ \\
\hline $\begin{array}{r}\text { Induced } \\
\text { lactation }\end{array}$ & 28.4 & $( \pm 1.8)$ & & & \\
\hline
\end{tabular}

(a) normal lactations (estimate of milk potential)

(b) mean $\pm S E(n=4)$.

The lactation curves of the 2 groups were different, group I goats maintaining a maximal yield between weeks 6 and 18, while the yield in group $N$ decreased (fig. 1). The lactation curve of hormonally-induced goats resembled that of goats which aborted (Chilliard et al., 1978).

Hormonally-induced animals consumed enough feed from the first week of lactation to satisfy their energy and protein requirements, contrary to normal goats (weeks 9 and 3, respectively) (see Chilliard, 1985). Thus limited nutrient availability was probably not the reason for the low milk yield of group I goats.

However, the relative failure of the hormonal treatment might have been partly due to the fact that it was given during a short-day period (December), as indicated by various observations in cows (Kensinger et al., 1979 ; Davis et al., 1981 ; Johke et al., 1981) and goats (De Montigny et al., 1978; Hart and Simmonds, 1982) as well as in pregnant ewes (Bocquier et al., 1986).

Mammary metabolism. - Few significant differences between groups or between lactation stages were noted, as regards DNA level, RNA/DNA ratio, lipogenic enzyme activities and $\beta$-CAS percentage (table 2). The same was true of enzyme activities as related to DNA. The wide variability in the results between animals and between lactation stages could reflect some heterogeneity in the tissue taken by biopsy. 


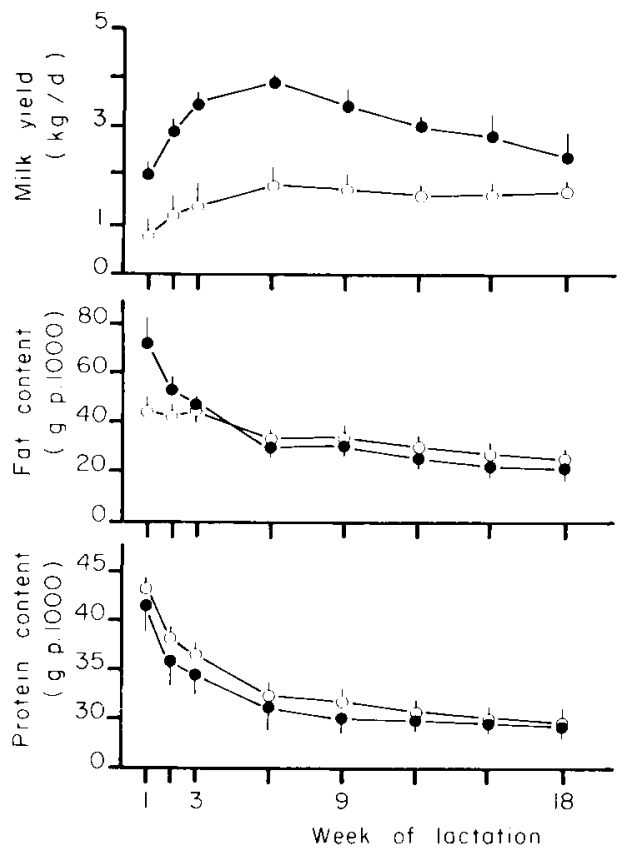

FIG. 1. - Milk yield, and fat and protein contents in the milk of normal and hormonally-induced goats.

Mean \pm SE $(n=4)$. Differences in milk yield are significant at the $3 \%$ threshold at all stages of lactation, except in the first week $(P<0.06)$. Differences in fat and protein contents are nonsignificant except for fat content in the first week $(P<0.10)$.

Metabolic activities measured in vitro by other authors (Shirley, 1973; Marinez et al., 1976 ; Chilliard et al., 1978 ; Reddy and Ray, 1982 ; Sarma and Ray, 1984), studying cow and goat mammary tissue during normal lactation, reached a maximum during the first month of lactation. However in other reported cases, these activities (or the RNA/DNA ratio) were steady or else augmented up to the 5 th or 6 th month of lactation (Currie, 1972; Shirley, 1973; Knight and Peaker, 1984). A decrease in mammary DNA level between weeks 3 and 23 was also reported in the goat (Knight and Peaker, 1984).

The absence of a relationship between mammary enzyme activities and secretion of the different milk components suggests that the measured enzyme potential did not necessarily reflect the intensity of the metabolic pathways as they operate in vivo. For example, there was no relationship between ACX and G6PDH activities and the levels of capric and lauric acids in the milk fat (table 2), although these acids are synthesized by a metabolic pathway involving both enzymes. As regards the intensity of the metabolic pathways, it should be noted that $\mathrm{ACX}$ activity could be inhibited in vivo by long-chain (C16-C18) fatty acids (Numa, 1981) (table 2).

Moreover, the metabolic potential per gram of tissue or in proportion to mammary DNA was comparable in hormonally-induced goats and normal animals. It is thus probable that the lower milk yield of the former resulted from a 


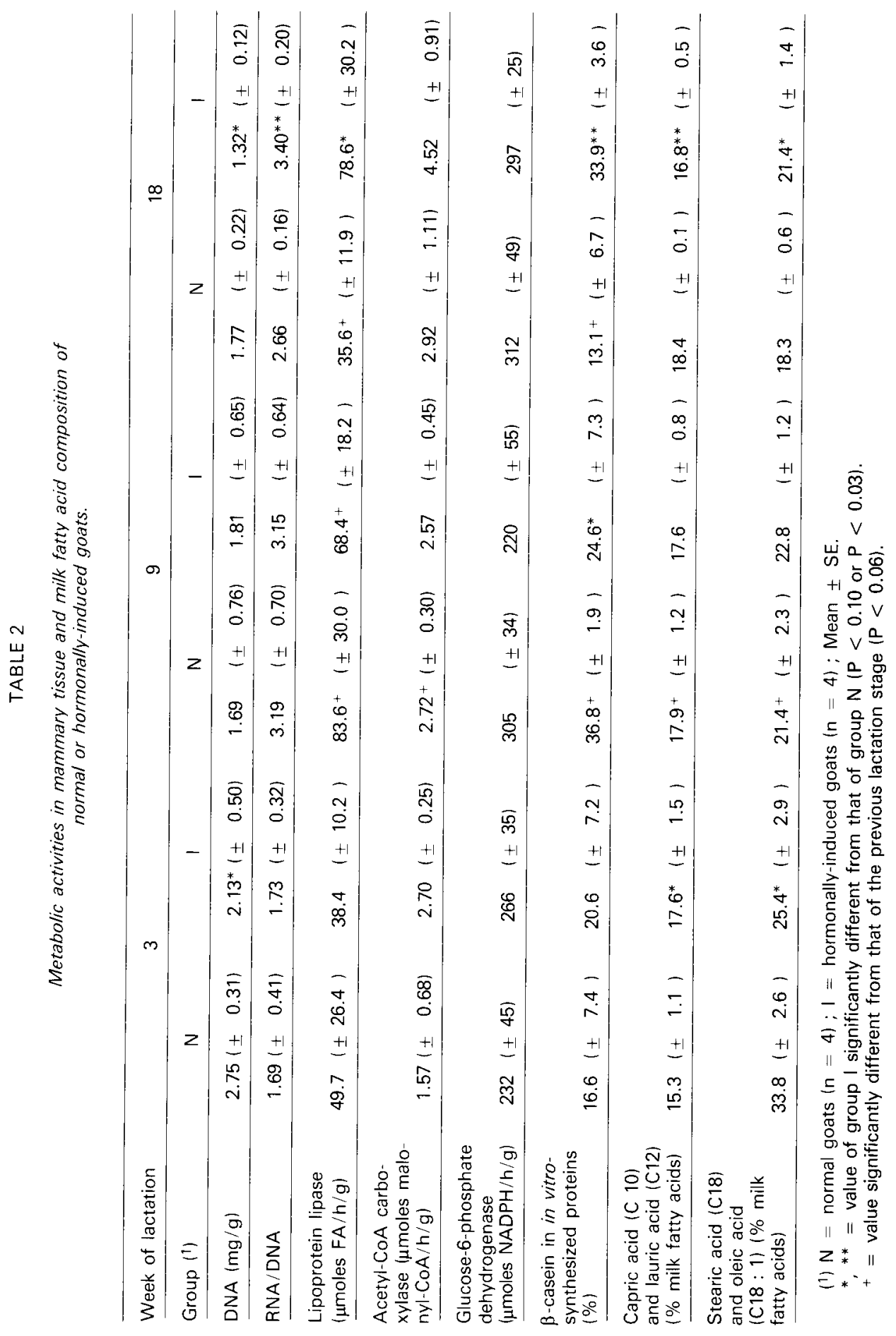


lower secretory cell hyperplasia, while induced lactation was being established, since no nutrient defiency was noted in these goats (see above). Collier et al. (1976) reported differences in the in vitro metabolic activities of the mammary tissue of 4 hormonally-induced cows for 2 weeks before and one week after milking was begun. These activities reflected differences in milk yield. It should be noted that measurements were carried out earlier than in the present study after the onset of the induction treatment had begun.

Fleming (1977) reported that when lactation was hormonally-induced in cows, a progressive differentiation of mammary cells could occur up to 30 to 110 days after hormone injections. Such a " delayed effect " could explain the better milk yield persistency in hormonally-induced goats (fig. 1), as well as the trend toward higher metabolic activities in mammary tissue at the 18 th week of lactation (table 2).

The composition of secreted milk was analogous in both groups (fig. 1). However the milk fat of normal goats contained higher levels of oleic and stearic acids, and fewer medium-chain fatty acids (C10 to $\mathrm{C} 16$ ) during the first weeks of lactation. The more intense mobilization of body lipids in these animals as opposed to hormonally-induced goats can account for these differences (see Chilliard, 1985 and table 2). This might partly explain the higher milk fat content $(P<0.10)$ observed in normal goats the first week. The drop (non-significant) in milk protein content in normal goats (fig. 1) might be partly due to the "dilution " effect of the fluid part of the milk and partly to the energy deficiency of these animals (Rémond, 1985).

Milk LPL activity. - Milk LPL activity in normal goats at the onset of lactation was very low. It then increased up to the 9 th week of lactation (fig. 2) in agreement with Bjorke and Castberg (1976) and Chilliard et al. (1981).

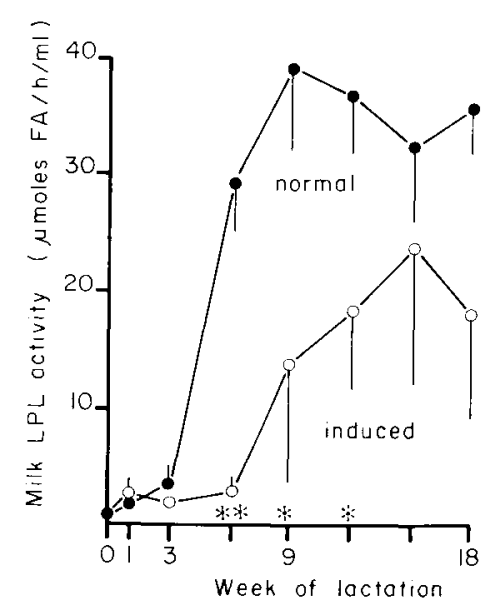

FIG. 2. - Changes in milk LPL activity in normal and hormonally-induced goats. Mean $\pm S E(n=4)$. $*: \mathrm{p}<0.10 ; * * \mathrm{P}<0.03$. 
The LPL activity in the milk of hormonally-induced goats was significantly lower at the peak of lactation than in normal goat milk (weeks 6 to 12). No significant differences were noted between the 2 groups from the 15 th week of lactation onwards. This lack of difference was confirmed in 42 Saanen breed goats (18 normal and 24 induced) in full lactation (Y. Chilliard and C. Delouis, unpublished data).

Neither the evolution of milk LPL activity nor the differences between groups were related to mammary tissue LPL activity. The secretory mechanisms of this enzyme in milk are not known. The LPL is probably synthesized in the secretory cells and then migrates to the capillary endothelium, which is its normal site of action. However, a portion of the enzyme also escapes into the milk (Olivecrona et al., 1975 ; Chilliard et al., 1979). The low levels of secretion at the onset of lactation, particularly in hormonally-induced goats, could reflect a sparing mechanism of the enzyme which is primarily directed towards the mammary hydrolysis of circulating lipids. A comparable process is observed when the animals are given a high-lipid diet (Chilliard et al., 1981).

\section{Conclusion.}

The composition of the milk of goats that have been hormonally induced to lactate is similar to that of normal goats. Potential mammary enzyme activities are also comparable. The lower milk yield of hormonally-induced goats may be partly due to a lower hyperplasia in the mammary secretory cells during hormonal treatment, especially if the treatment is given during a short-day season. The qualitative differences observed are mainly a slower rise in the milk lipoprotein lipase content and, due to less body lipid mobilization, a lower proportion of longchain fatty acids in the milk fat secreted at the onset of induced lactation.

$11^{e}$ Réunion du groupe Développement I.N.R.A., Montpellier, 22-24 mai 1985.

Résumé. Métabolisme mammaire de la chèvre pendant la lactation normale ou induite par des hormones.

Le métabolisme mammaire a été étudié chez 4 chèvres pendant une lactation normale (lot $N$ ) et 4 chèvres non gravides pendant une lactation induite par traitement hormonal (Lot I). Le tissu était prélevé par biopsie en $3^{e}, 9^{e}$ et $18^{e}$ semaine de lactation. Bien que les deux lots aient le même potentiel laitier, les chèvres du lot 1 ont produit $45 \%$ de lait de moins que celies du lot $\mathrm{N}$.

Le rapport ARN/ADN, les activités de la lipoprotéine-lipase (LPL), de la glucose-6phosphate déshydrogénase et de l'acétyl-CoA carboxylase, et le pourcentage de caséine- $\beta$ dans les protéines synthétisées in vitro n'étaient pas plus faibles dans le tissu mammaire des chèvres du lot I que dans celui des chèvres du lot $N$. Ceci suggère que ce sont des différences dans I'hyperplasie des cellules mammaires pendant le traitement hormonal, et non les activités métaboliques potentielles, qui expliquent en partie les différences de production laitière.

La composition du lait était comparable dans les deux lots. Toutefois, la matière grasse du lait du lot $\mathrm{N}$ était plus riche en acides gras à longue chaîne (acides stéarique et oléique) pendant le premier mois de lactation, en raison de la plus forte mobilisation des lipides corporels chez les animaux forts producteurs. Une autre différence qualitative réside dans l'augmentation plus lente de la sécrétion de LPL dans le lait, observé chez les chèvres induites pendant les 3 premiers mois de lactation. 


\section{Références}

BAS P., 1985. Extraction rapide de la matière grasse du lait pour la détermination de sa composition en acides gras. Cah. Techn. I.N.R.A., 9, 21-24.

BJORKE K., CASTBERG H. B., 1976. Lipolytic activity in goat's milk. Nordeurop. Mejeri-Tidsskrift, 8, 296-304.

BOCQUIER F., THÉRIEZ M., KANN G., DELOUIS C., 1986. Influence de la photopériode sur la partition de l'énergie nette entre la production laitière et les réserves corporelles chez la brebis traite. Reprod. Nutr. Dévelop., 26, 389-390.

CHILLIARD Y., 1979. Lipoprotein lipase of goat mammary tissue : comparison of extraction methods J. Dairy Res., 46, 599-605.

CHILLIARD Y., 1985. Métabolisme du tissu adipeux, lipogenèse mammaire et activité lipoprotéinelipasiques chez la chèvre au cours du cycle gestation-lactation (134 pp. 1323 réf.). Th. Doct. Etat ès-Sci Univ. Paris 6 (France).

CHILLIARD Y., FEHR P. M., 1976. Activité lipolytique du lait de chèvre. I. Mise en évidence d'une activité lipoprotéine-lipasique. Ann. Techn. agric., 25, 219-230.

CHILLIARD Y., SAUVANT D., MORAND-FEHR P., 1979. Goat mammary, adipose and milk lipoprotein lipases. Ann. Rech. vét., 10, 401-403.

CHILLIARD Y., SAUVANT D., MORAND-FEHR P., DURAND G., 1978. Evolution du métabolisme lipidique du tissu mammaire chez la chèvre au cours des 2 premiers mois de lactation. $C . R$. Acad. Sci. Paris, Sér. D, 287, 871-874.

CHILLIARD Y., SELSELET-ATTOU G., BAS P., MORAND-FEHR P., 1981. Facteurs influençant la lipolyse du lait de chèvre $6^{e}$ Journ. Rech. Ovine et Caprine (I.N.R.A., ITOVIC), 332-350. (Ed ITOVIC-SPEOC).

COLLIER R. J., CROOM W. J., BAUMAN D. E., HAYS R. L., NELSON D. R., 1976. Cellular studies of mammary tissue from cows hormonally induced into lactation : lactose and fatty acid synthesis. J. Dairy Sci., 59, 1226-1231.

CURRIE W. B., 1972. Trans-lactation changes in the activities of selected enzymes in biopsy samples of the bovine mammary gland. Aust. J. biol. Sci., 25, 1333-1340.

DAVIS S. R., WELCH R. A. S., PEARCE M. G., PETERSON A. J., 1981. The hormonal induction of lactation in dry dairy cows. Proc. N. Z. Soc. anim. Prod., 41, 68-70.

DE MONTIGNY G., PONT J., DELOUIS C., 1978. Induction de la lactation chez la chèvre, production laitière et fertilité ultérieure. In 4 Journ. Rech. Ovine et Caprine, 350-357. (I.N.R.A.ITOVIC Ed).

DELOUIS C., 1975. Induction hormonale de la lactation chez la chèvre. fre Journ. Rech. Ovine et Caprine., (I.N.R.A.-ITOVIC), 64-72.

FITCH W. M., HILL R., CHAIKOFF I. L., 1959. The effect of fructose feeding on glycolytic enzyme activities of the normal rat liver. J. biol. Chem., 234, 1048-1051.

FLEMING J. R., 1977. Histological, biochemical, and ultrastructural changes associated with hormone induced lactation in the dairy cow. M. S. Thesis, Florida Univ., USA.

HART I. C., SIMMONDS A. D., 1982. The effect of day length on induced mammary growth and lactation in goats. Nat. Inst. Res. Dairying, Rep. 1981, 63 (Abstract).

JOKHE T., HODATE K., HODATE K., TAKAHASHI T., 1981. Effects of reserpine and season on plasma prolactin, growth hormone, and lactogenesis in hormonally induced lactation of dairy heifers. Jap. J. Zootech. Sci., 52, 63-66.

KENSINGER R. S., BAUMAN D. E., COLLIER R. J., 1979. Season and treatment effects on serum prolactin and milk yield during induced lactation. J. Dairy Sci., 62, 1880-1888.

KNIGHT C. H., PEAKER M., 1984. Mammary development and regression during lactation in goats in relation to milk secretion. Quart. J. exp. Physiol., 69, 331-338.

MARINEZ D. I., RICKS C. A., COOK R. M., 1976. Utilization of volatile fatty acids in ruminants. 8. Acetate activation in mammary tissue. J. agric. Food Chem., 24, 927-935.

NUMA S., 1981. Two long-chain acyl coenzyme A synthetases : their different roles in fatty acid metabolism and its regulation. Trends Biochem. Sci., 6, 113-115.

OLIVECRONA T., EGELRUD T., HERNELL O., CASTBERG H., SOLBERG P., 1975. Is there more than one lipase in bovine milk? Proc. of the Lipolysis Symp.-Cork. Bull. Fed. int. Laiterie, Doc., 86, 61-72. 
PASCAL G., DURAND G., MACAIRE J. P., PENOT E., 1977. Evolution de l'activité de l'acétylCoA-carboxylase et de la lipoprotéine-lipase dans le foie et les tissus adipeux du rat mâle au cours du développement après sevrage. Ann. Biol. anim. Bioch. Biophys., 17, 827-849.

REDDY K. V. S., RAY T., 1982. Enzymes associated with fatty acid synthesis in goat mammary tissue at different stages of lactation. Ind. J. Biochem. Biophys., 19, 333-335.

REMOND B., 1985. Influence de l'alimentation sur la composition du lait. 2. - Taux Protéique : facteurs généraux. Bull. Tech. CRVZ-Theix, I.N.R.A., 62, 53-67.

SARMA P. V., RAY T. K., 1984. Fatty acid synthesizing capacity of mammary gland in relation to plasma hormone levels at different stages of pregnancy and lactation in goats. Ind. J. Biochem. Biophys., 21, 255-259.

SCHMIDT G., TANNHAUSER S. J., 1945. A method for the determination of deoxyribonucleic acid, ribonucleic acid, and phosphoproteins in animal tissues J. Biol. Chem., 161, 83-89.

SHIRLEY J. E., 1973. Regulatory aspects of triglyceride uptake by bovine adipose and marnmary tissues. Ph. D. thesis, Michigan State Univ., East Lansing (USA).

SKARDA J., URBANOVA E., HOUDEBINE L. M., DELOUIS C., BILEK J., 1982. Effects of insulin, cortisol and prolactin on lipid, protein and casein synthesis in goat mammary tissue in organ culture. Reprod. Nutr, Dévelop., 22, 379-386.

TOMASSONE R., 1981. Statistique non paramétrique. Document polycopié (Institut National Agronomique Paris-Grignonl. 